\title{
KNOWLEDGE AND ATTITUDES OF PUERPERAL WOMEN RELATING TO BREASTFEEDING IN A UNIVERSITY HOSPITAL
}

\author{
SABERES E ATITUDES DE PUÉRPERAS SOBRE O ALEITAMENTO \\ MATERNO EM UM HOSPITAL UNIVERSITÁRIO
}

\begin{abstract}
Alderi Lopes RABELO ${ }^{1}$; Ana Carolina Cardoso BORGES ${ }^{2}$; Carlos Henrique REZENDE ${ }^{3}$; Rogério Melo Costa PINTO ${ }^{4}$; Vânia Olivetti Steffen ABDALLAH

1. Obstetrician Nurse of the Hospital de Clínicas of the Federal University of Uberlândia. Post Graduate Program in Health Sciences, Uberlândia, MG, Brazil; 2. Nutritionist of the Hospital de Clínicas of the Federal University of Uberlândia, Uberlândia, MG,- Brazil; 3. Associate Professor of the Department of Internal Medicine of the Faculty of Medicine of the Federal University of Uberlândia, Uberlândia, MG, Brazil; 4. Associate Professor of the Mathematics Faculty of the Federal University of Uberlândia, Uberlândia MG, Brazil; 5. Principle Professor of the Department of Pediatrics of the Faculty of Medicine of the Federal University of Uberlândia, Uberlândia MG, Brazil
\end{abstract}

\begin{abstract}
Breastfeeding (BF) has presented, among other benefits, a reduction in infant mortality, a prevention of respiratory infections and a reduction in the risks of developing diseases. Therefore, the objectives of this study were to evaluate the knowledge and attitudes of puerperal in relation to BF in a university hospital, as well as the sources from which this information was obtained and the professional categories responsible for same. The work was carried out at the Hospital das Clinicas, Federal University of Uberlândia (HC-UFU). Structured interviews were conducted to obtain data for the evaluation of information and exercise of the BF practice with puerperal hospitalized in the accommodation complex, for mother and child, from July $1^{\text {st }}$ to December $31^{\text {st }}, 2010$. Of the total of 907 women interviewed, $617(68.0 \%)$ intended to $\mathrm{BF}$ for 12 months or more, $566(62.4 \%)$ performed the BF within the first hour of birth, in 551 cases $(60.8 \%)$ the decision to BF was taken by the woman before the current pregnancy and $828(91.3 \%)$ received help in BF. Of the women who received help, 788 (95.1\%) were assisted by professionals from the nursing team. It was shown that the majority of the puerperal intended to breast-feed for 12 months or more, considering that they also carried out BF in the first hour after child birth. The study also noted the importance of the nursing staff in taking care of the mother/child pair, promoting better interaction and acceptance of BF.
\end{abstract}

KEYWORDS: Breastfeeding. Knowledge. Pre-natal. Puerperal. Newborn

\section{INTRODUCTION}

In recent years there has been an important advance in attention to the clinical management of breastfeeding (BF) as well as in conducting research on this topic (KOKSAL, 2015). The World Health Organization recommends that exclusive breastfeeding (EBF) be started from birth and continued until the 6th month of age, introducing complementary foods as from 6 months and the BF to continue until the child is two years of age or more (BRASIL, 2014).

A number of authors discuss and demonstrate the benefits of EBF in the first six months of life for the child and point out that human milk is essential to reduce infant morbid mortality. In addition, the EBF helps prevent respiratory infections, reduces the risk of developing diseases, promotes the affective mother/child bond and the best psychomotor and cognitive development, with the consequent increase of the individual's quality of life (SOUZA, 2013; AYTEKIN, 2014).

Women's knowledge and attitudes have an impact on various aspects of $\mathrm{BF}$, such as establishment and its duration. Studies show that by improving the attitudes of mothers in relation to the act of breastfeeding, especially among those who are younger and of lower level of awareness in early pregnancy can significantly increase the duration of the BF and promote its earlier start (SHAMS, 2011; QUEENAN, 2011). Despite the relevance of the theme, few studies as to the barriers and lived experiences of women have been published (AMERICAN ACADEMY OF PEDIATRICS, 2012).

Strategies to promote, protect and support $\mathrm{BF}$ should include a component of information, education and communication, in order to influence mothers and family members through knowledge about BF (WALLWIENER, 2015). The greater and more qualified the knowledge about $\mathrm{BF}$ among women, the more confident they will be with their personal abilities to breastfeed (SHARP, 2015).

In this context, the objectives of this study were to evaluate the knowledge, the puerperal attitudes about BF in a university hospital, as well as the sources from which this information was obtained and the professional categories responsible for same. 


\section{MATERIAL AND METHODS}

\section{Procedures}

The work was carried out at the Hospital das Clinicas, Federal University of Uberlândia (HCUFU). The study population consisted of puerperal admitted to the Accommodation Complex, aged from 10-50 years old. All puerperal in the period from July $1^{\text {st }}$ to December $31^{\text {st }} 2010$ who agreed to participate in the survey and signed the free and informed consent form (ICF) were included. The under 18 women were included within the same criteria and the ICF was signed by their legal representatives. The puerperal who had conditions that indicated against $\mathrm{BF}$ were excluded, those carrying the Human Immunodeficiency Virus (HIV), human T cell lymphotropic virus (HTLV), and those who refused to participate in the survey as well as those infant was admitted to or transferred to the Neonatal Unit (NU).

The puerperal were invited to participate in the interview, between six and twenty-four hours after delivery. At that time, the study proposal was presented and possible doubts were clarified. After signing the ICF, the woman was interviewed by a previously trained member of staff. The structured interview had an average duration of 15 minutes, and the questions were asked orally by the interviewer. The questionnaire consisted of 23 questions with multiple choice answers (Annex 1). It was structured on the basis of other researches on BF (CALDEIRA, 2000; NAKAMURA, 2003,
RABELO, A. L. et al.

MARRONE, 2008). It was made up of six socio demographic questions (1-6); six obstetric (7-12), eight $\mathrm{BF}(12-20)$ and three questions about the support of health professionals for BF (21-23). So that no interference could occur in the results of the study, the approach to the woman, and the interview, always took place before having educational lectures about $\mathrm{BF}$ for the studied group.

This study was approved by the Ethics Committee of the Federal University of Uberlândia MG, under protocol number 107/2010.

\section{Data analysis}

The results were described in frequencies that were absolute and showed percentage. So as to evaluate the association of socio demographic variables and information about $\mathrm{BF}$, the ChiSquared Test $\left(\chi^{2}\right)$ was used, considering as statistically significant those results with $p<0,05$. All the statistical analyzes were carried out using the SPSS program, version 17.0 (Statistical Package for Social Science, 2008).

\section{RESULTS}

Nine hundred and seven (907) percentuais of the 1,206 women who gave birth in the HCUFU during the study period were interviewed. The main reason for exclusion was the transfer of the newborns to the progressive care Neonatal Unit $(n=262)$. Other reasons for non-inclusion in the study group are shown in Figure 1.

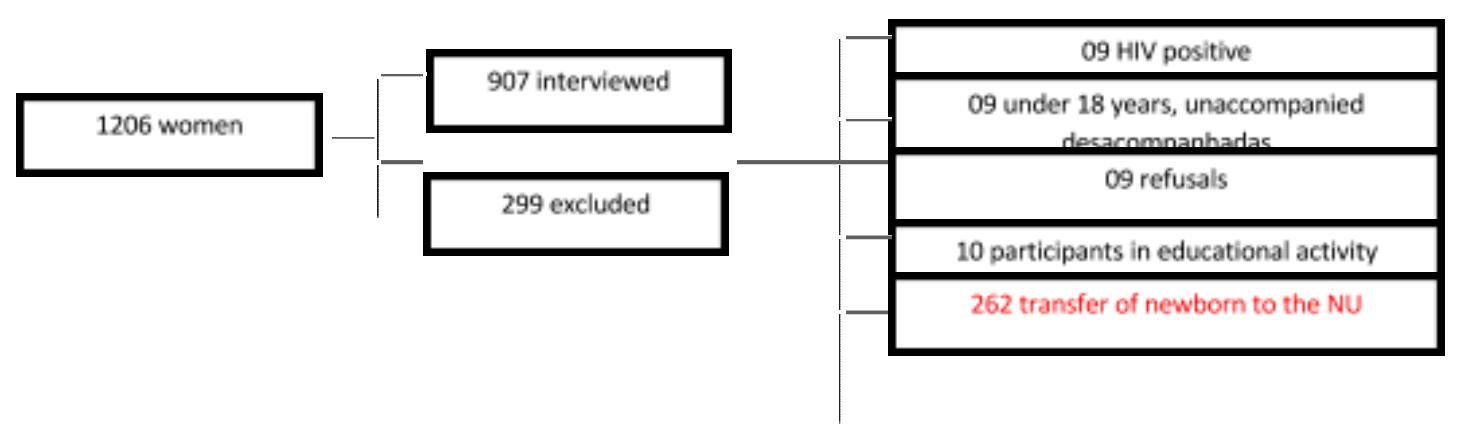

Figure 1. Distribution of women who gave birth within the study period.

The socio-demographic and gestational characteristics of the women interviewed are described in Table 1 . It was found that $61 \%$ were less than 25 years of age, $75 \%$ had not completed high school and $57.3 \%$ had a stable union. 
Table 1. Socio-demographic and gestational characteristics of the women interviewed, Uberlandia (MG) 2010/2011.

\begin{tabular}{|c|c|c|}
\hline Variable & $\mathrm{n}$ & $(\%)$ \\
\hline \multicolumn{3}{|l|}{ Age } \\
\hline$<25$ years & 520 & 57,3 \\
\hline$\geq 25$ years & 387 & 42,7 \\
\hline \multicolumn{3}{|l|}{ Origin } \\
\hline Uberlândia & 850 & 93,7 \\
\hline \multicolumn{3}{|l|}{ Marital Status } \\
\hline Stable union & 680 & 75,0 \\
\hline \multicolumn{3}{|l|}{ Occupation } \\
\hline Housewife & 525 & 57,9 \\
\hline \multicolumn{3}{|l|}{ Education } \\
\hline High school incomplete & 553 & 61,0 \\
\hline High school and Higher education & 354 & 39,0 \\
\hline \multicolumn{3}{|l|}{ Family income (in minimum wages) } \\
\hline From 1 to 3 & 769 & 84,8 \\
\hline \multicolumn{3}{|l|}{ Prenatal care } \\
\hline Yes & 889 & 98,0 \\
\hline \multicolumn{3}{|l|}{ Number of Consultations } \\
\hline Six or more & 793 & 89,2 \\
\hline \multicolumn{3}{|l|}{ Type of prenatal care } \\
\hline Public & 862 & 96,9 \\
\hline \multicolumn{3}{|l|}{ Gestational age at delivery } \\
\hline$\geq 37$ weeks & 826 & 91.0 \\
\hline \multicolumn{3}{|l|}{ Parity } \\
\hline First time & 341 & 37,6 \\
\hline
\end{tabular}

In all, $617(68.0 \%)$ of the women reported that they intended to BF for 12 months or more, 566 $(62.4 \%)$ of the women had BF within the first hour after birth. The decision to BF was taken by the women before the present pregnancy in 551 $(60.8 \%)$ of the cases and $467(51.5 \%)$ of the respondents reported having received information about BF during prenatal care. The beginning of complementary feeding is intended until the 6th month of life of the child in $816(90.0 \%)$ cases. After delivery, 219 (24.1\%) women reported having received guidance on $\mathrm{Bf}$ and $828(91.3 \%)$ received help as regards to the breastfeeding process. The main professional category responsible for the technical support as to BF was the nursing staff, with $788(72.7 \%)$ women being assisted by these professionals (Table 2). 
Table 2. Answers to the questionnaire on information, orientation and aspects related to BF, Uberlandia (MG) $2010 / 2011$

\begin{tabular}{|c|c|c|}
\hline Variable & $\mathrm{n}$ & $\%$ \\
\hline \multicolumn{3}{|c|}{ Information on BF during pregnancy } \\
\hline Yes & 467 & 51,5 \\
\hline \multicolumn{3}{|l|}{ Source of information on $\mathrm{BF}$} \\
\hline prenatal & 362 & 73,0 \\
\hline \multicolumn{3}{|l|}{ Intended time for BF } \\
\hline$<6$ months & 18 & 2,0 \\
\hline 6 months & 272 & 30,0 \\
\hline 12 months or more & 617 & 68,0 \\
\hline \multicolumn{3}{|l|}{ BF in the first hour of life } \\
\hline Yes & 566 & 62,4 \\
\hline \multicolumn{3}{|l|}{ Decision to breastfeed } \\
\hline Previous to pregnancy & 551 & 60,8 \\
\hline During pregnancy & 229 & 25,2 \\
\hline After the birth of the child & 127 & 14,0 \\
\hline \multicolumn{3}{|c|}{ Intend to begin complimentary feeding } \\
\hline Up to 6 months of life & 816 & 90,0 \\
\hline Over 6 months & 23 & 2,5 \\
\hline Did not know how to answer & 68 & 7,5 \\
\hline \multicolumn{3}{|l|}{ Orientations on BF after delivery } \\
\hline Yes & 219 & 24,1 \\
\hline \multicolumn{3}{|l|}{ Professional Category } \\
\hline Nursing staff & 181 & 61,8 \\
\hline Pediatrician & 93 & 31,7 \\
\hline \multicolumn{3}{|l|}{ Help for BF after delivery } \\
\hline Yes & 828 & 91,3 \\
\hline \multicolumn{3}{|l|}{ Professional Category } \\
\hline Nursing staff & 788 & 72,7 \\
\hline Pediatrician & 231 & 21,3 \\
\hline
\end{tabular}

The analysis of socio demographic, obstetric (prenatal, gestational age, parity) and BF data in relation to information received about breastfeeding
(Table 3) showed a statistically significant association regarding education $(P=0,007)$, prenatal $(P=0,046)$, gestational age $(P=0,003)$ and decision 
to breastfeed $(P<0,006)$. Private prenatal care showed itself to be associated with the highest levels of education, occupancy rate and family income
$(\mathrm{P}<0,001)$, and with less information about $\mathrm{BF}$ $(\mathrm{P}<0,046)$.

Table 3. Association between obstetric variables, prenatal and information received about BF, Uberlandia (MG), 2010/2011.

\begin{tabular}{|c|c|c|c|c|}
\hline \multirow[t]{2}{*}{ Variable } & \multicolumn{4}{|c|}{ Information on AM } \\
\hline & No & Yes & & \\
\hline Education & & & Total & \\
\hline $\begin{array}{l}\text { No schooling to fundamental schooling } \\
\text { incomplete }\end{array}$ & $149(55,6 \%)$ & $119(44,4 \%)$ & 268 & $P=0,007^{*}$ \\
\hline $\begin{array}{l}\text { Fundamental schooling complete to medium } \\
\text { incomplete }\end{array}$ & $139(48,8 \%)$ & $146(51,2 \%)$ & 285 & \\
\hline $\begin{array}{l}\text { Medium schooling complete to superior } \\
\text { schooling complete }\end{array}$ & $152(42,9 \%)$ & $202(57,1 \%)$ & 354 & \\
\hline \multicolumn{5}{|l|}{ Type of pre-natal ${ }^{1}$} \\
\hline Public & $407(47,2 \%)$ & $455(52,8 \%)$ & 862 & $P=0,046^{*}$ \\
\hline Private & $18(66,7 \%)$ & $9(33,3 \%)$ & 27 & \\
\hline \multicolumn{5}{|l|}{ Gestational age } \\
\hline Term & $393(47,6 \%)$ & $433(52,4 \%)$ & 826 & $P=0,003^{*}$ \\
\hline Pre-term & $47(62,7 \%)$ & $28(37,3 \%)$ & 75 & \\
\hline Post-term & $0(0,0 \%)$ & $6(100,0 \%)$ & 6 & \\
\hline \multicolumn{5}{|l|}{ Decision to breastfeed } \\
\hline Before pregnancy & $258(46,8 \%)$ & $293(53,2 \%)$ & 551 & $P=0,006^{*}$ \\
\hline During pregnancy & $109(47,6 \%)$ & $120(52,4 \%)$ & 229 & \\
\hline After the birth of the child & $73(57,5 \%)$ & $54(42,5 \%)$ & 127 & \\
\hline
\end{tabular}

$* X^{2}$ The total number for the variable 'Type of prenatal' is 889 , as 18 women did not have monitoring during pregnancy.

\section{DISCUSSION}

Breastfeeding (BF) is the most natural form of newly born nutrition. It provides psychological and health benefits for both the mother and the child. The decision to BF is complex and depends on multiple factors such as biological, psychological, social and educational (SILVA, 2013; SEIGHALI, 2015).

The education of mothers as to the importance and duration of $\mathrm{BF}$ is essential for the establishment of BF which results in promoting the health of the children (SEIGHALI, 2015). Among the main factors contributing to the success BF are included personal convictions, family influence and the support of health professionals (BARCLAY, 2012).
A number of authors have discussed the factors associated with $\mathrm{BF}$ on a worldwide basis, among which the influence of socio demographic characteristics of the percentuais are worthy of note. Thus, the discussion of these variables can reveal cultural trends of a population group as regards BF (SILVA, 2013; BIKS, 2015; SALUSTIANO, 2012).

The results of this study show a young age pattern with an average age of 24.9 years (13-44 years) compared to other studies (SILVA, 2013; SALUSTIANO, 2012). At HC-UFU a significant number of births by adolescent mothers (21.6\%) was also observed compared to $14.6 \%$ of the overall average for the municipality of the area of research (BRASIL, 2012a).

According to Barbieri, the marital status of the woman may be linked to the success of $\mathrm{BF}$ (BARBIERI, 2015), in the present study findings 
corroborate this fact. Of the 907 women who accepted BF well, $75 \%$ had a stable relationship. The level of education of the woman also shows itself to be relevant to the investigation as to the knowledge, attitudes and practices related to $\mathrm{BF}$ (FOX, 2015). In this study, the level of education of most of the women was high school or university graduate. Similar results have been described in other studies (SILVA, 2013; SALUSTIANO, 2012). The HC-UFU, whose attendance or service is exclusively through the Unified Health System of Brazil, serves a population with lower purchasing power. Although most respondents have completed high school or university, this study showed that family income was between one and three minimum wages for the majority of the women. Moreover, most of them (57.9\%) were housewives, not exercising any academic or paid activity.

One important factor for the success of BF is prenatal, where it is recommended that the mother to be carries out at least six consultations, be they in the public or in the private health network (OLIVEIRA, 2012). The pregnancy period has been considered an opportune time for appropriate guidelines to be given as to $\mathrm{BF}$ and prepare the mother to be for BF (BRASIL, 2012b). The public health system in the municipality of Uberlândia has installed a prenatal program with dissemination and incentive for its accomplishment. This study showed that $96.9 \%$ of the women, who underwent prenatal in the public service, had a minimum of six visits, similar to the guidance from the Ministry of Health (MAZARIEGOS, 2015; BRASIL, 2012a).

The results of this study show that prenatal care was the main source of information as to BF. Despite the significant number of percentuais $(48.5 \%)$ who did not receive information about BF during the last pregnancy, those who received $(51.5 \%)$ obtained the information during the prenatal period, reinforcing the importance of this practice during pregnancy. The Ministry for Health annually launches advertising campaigns in support of $\mathrm{BF}$, valuing its airing through the media (BRASIL, 2012b). Thus, it is worth noting that in the group investigated $18.8 \%$ of the women indicated the media as a source of information as to BF.

The intention of the women regarding the duration of $\mathrm{BF}$ found in the study is at least 12 months of a child's life for $68.0 \%$ of the participants. This result agrees with the research carried out in the Brazilian state capitals where the medium or average duration of 11.2 months of $\mathrm{BF}$ was found (VENANCIO, 2013). This study reveals a promising outlook when compared to the results found in a study developed in Jordan, where 37\% of mothers considered a three months period as the adequate time to breastfeed their children (GRIMSHAW, 2013).

The study carried out in Brazilian state capitals and in the Federal District, the results indicated the panorama of $\mathrm{BF}$ in the country (VENANCIO, 2013). The percentage of children who were breastfed in the first hour was $67.7 \%$ in the country, with the Southeast averaging less than the national value with $63.5 \%$ of children breastfed in the first hour of life. According to these parameters from the $\mathrm{WHO}$ for $\mathrm{BF}$ in the first hour of life, Brazil is classified as "Good" with percentage variation of $50-89 \%$ of $\mathrm{BF}$ in the first hour. This study shows similar data, with $62.4 \%$ of the women interviewed carrying out $\mathrm{BF}$ in the first hour of life of the child. It is important to mention that only the woman's intention to breastfeed does not guarantee the complete success of the practice. It requires the attention from health teams, as they are the health professionals who are fundamental for the success of $\mathrm{BF}$ and who perform an educational role in promoting breastfeeding and prevention early weaning (SILVA, 2014).

According to Hackman e Alves, the greater the level of education, the better the type of prenatal care the more likely will be the decision to breastfeed. Supported by such data, when variables associated with the received information about breastfeeding were evaluated, the results were statistically significant for higher education, type of prenatal care, gestational age and decision to breastfeed (HACKMAN, 2015; ALVES, 2013).

Pregnancy is an important time to orientate and raise the awareness of woman as to BF. For some authors, education on BF practices should occur before pregnancy, from the early school years so that children and young people could learn about the advantages of $\mathrm{BF}$, its establishment and maintenance in addition to the importance of this practice for the child's development (OOSTERHOFF, 2014). A finding of this study was that $60.8 \%$ of the women interviewed had decided to breast-feed before pregnancy, probably due to information and experience acquired previously.

As regards the investigation of the association of the type of prenatal carried out, be it public or private, and the studied variables, such as education, occupation, family income and information as to $\mathrm{BF}$, statistically significant differences were found. Most of the women (90\%) carried out the monitoring of pregnancy in the Free public health sector, so that the assessment may not be real due to the low number of women, 27 (3.1\%), 
who underwent prenatal care in the private service sector.

The health workers of the hospital investigated developed educational and caring activities related to $\mathrm{BF}$. It is expected that teaching hospitals be committed not only to caring, but also to education in health and research (SALUSTIANO, 2012). The results of this study show that the involvement of service nursing staff with issues related to $\mathrm{BF}$ was greater than that of other professional categories, probably due to greater contact with the mother and newborn and the development of ones function as a caregiver. Other studies have shown the important role of the nursing professionals in the promotion, support and encouragement as to BF. (SILVA, 2014; WARD; BYRNE, 2011).

After delivery 219 (24.1\%) women reported having received orientation on $\mathrm{BF}$ and 828 (91.3\%) received help in $\mathrm{BF}$. The main professional category responsible for the technical support as to $\mathrm{BF}$ was the nursing staff, of which $788(72.7 \%)$ women were assisted by these professionals. The results obtained from the study suggest that the training of health professionals, particularly nursing staff, could change the BF practice, as these are considered the main source of information for mothers, especially for the first time mothers (SILVA, 2014; WARD; BYRNE, 2011).

The current study, although it was carried out in only one hospital, suggests the need to implement health education programs focusing on BF not only for prenatal and likewise suggests the establishment of actions that enable all healthy mother-child binomials can experience the establishing of BF in the first hour post-partum.

\section{CONCLUSIONS}

The majority of the puerperal received information about BF during the current pregnancy, and the prenatal was referred to as the main source of information.

Nursing professionals are pointer out or mentioned as the main agents responsible for orientation and assistance in the establishment of breastfeeding.

RESUMO: O aleitamento materno tem, dentre outros benefícios, a diminuição da morbimortalidade infantil, a prevenção de infecções respiratórias e a redução dos riscos de desenvolvimento de doenças, portanto, os objetivos deste estudo foram avaliar os saberes e atitudes de puérperas sobre aleitamento materno em um hospital universitário, bem como as fontes de obtenção e as categorias profissionais responsáveis por essas informações. O trabalho foi realizado no Hospital das Clínicas da Universidade Federal de Uberlândia (HC-UFU). Foram realizadas entrevistas estruturadas para obtenção de dados para avaliação de informações e exercício da prática do AM com puérperas internadas no alojamento conjunto, entre $1^{\circ}$ de julho a 31 de dezembro de 2010. Do total de 907 entrevistadas, 617 (68,0\%) das mulheres pretendiam amamentar por 12 meses ou mais, $566(62,4 \%)$ das mulheres realizaram o AM já na primeira hora do nascimento, em 551 $(60,8 \%)$ a decisão de amamentar foi tomada pela mulher antes da gravidez atual e $828(91,3 \%)$ receberam ajuda no processo de amamentação. Das mulheres que receberam ajuda, $788(95,1 \%)$ foram auxiliadas por profissionais da equipe de enfermagem. Foi demonstrado que a maioria das puérperas pretendia amamentar por 12 meses ou mais, tendo em vista que também realizaram o AM na primeira hora. Observou-se também a importância da equipe de enfermagem para com o cuidado do binômio mãe/filho, fazendo com que houvesse melhor interação e aceitação do AM.

PALAVRAS CHAVE: Aleitamento materno. Saberes. Pré-natal. Puérpera. Neonato.

\section{REFERENCES}

ALVES, A. L. N.; OLIVEIRA, M. I. C.; MORAES, J. R.. Breastfeeding-Friendly Primary Care Unit Initiative and the relationship with exclusive breastfeeding. Public Health Journal, São Paulo, v. 47, n. 6, p.1130-1140, dez. 2013.

AYTEKIN, A.; ALBAYRAK, E. B.; KUÇUKOGLU, S.; CANER, I. The effect of feeding with spoon and bottle on the time of switching to full breastfeeding and sucking success in preterm babies. Türk Pediatri Arşivi, Erzurum, v. 49, n. 4, p. 307-313, 23 jan. 2015. https://doi.org/10.5152/tpa.2014.1904

American Academy of Pediatrics. Breastfeeding and the Use of Human Milk. Pediatrics, v. 129, n. 3, p.827841, 27 fev. 2012. https://doi.org/10.1542/peds.2011-3552 
BARBIERI, M. C.; BERCINI, L. O.; BRONDANI, K. J. M.; FERRARI, R. A. P. Aleitamento materno: orientações recebidas no pré-natal, parto e puerpério. Semin. Cienc. Biol. Saude, Londrina, v. 36, n. 1, p.1724, 4 jul. 2014.

BARCLAY, L.; LONGMAN, J.; SCHMIED, V.; SHEEHAN, A. The professionalising of breast feedingWhere are we a decade on? Midwifery, [s.1.], v. 28, n. 3, p.281-290, jun. 2012.

BIKS, G. A.; BERHANE, Y.; WORKU, A.; GETE, Y. K. Exclusive breastfeeding is the strongest predictor of infant survival in Northwest Ethiopia: a longitudinal study. J Health Popul Nutr, Gondar, v. 34, n. 1, p. 1-6, 1 maio 2015.

BRASIL. MINISTÉRIO DA SAðDE. . O DATASUS. 2011. Disponível em: $<$ http://www2.datasus.gov.br/DATASUS/index.php?area=01>. Acesso em: 21 jul. 2012a.

BRASIL. MINISTÉRIO DA SAUDE. Amamentação traz benefícios para a mãe e o bebê. 2011. Disponível em: <http://www.brasil.gov.br/saude/2011/10/amamentacao-traz-beneficios-para-a-mae-e-o-bebe>. Acesso em: 10 jul. $2012 b$.

BRASIL. MINISTÉRIO DA SAUDE. . HUMANIZAÇÃO DO PARTO E DO NASCIMENTO. Brasilia: Ms, 2014. 465 p. 4 v. Disponível em:

$<$ http://www.redehumanizasus.net/sites/default/files/caderno_humanizasus_v4_humanizacao_parto.pdf>. Acesso em: 12 jul. 2014.

CALDEIRA, A. P.; GOULART, E. M. A.. A Situação do aleitamento materno em Montes Claros, Minas Gerais: estudo de uma amostra representativa. J. Pediatr., v. 76, n. 1, p. 65-72. 2000.

https://doi.org/10.2223/JPED.35

FOX, R.; MCMULLEN, S.; NEWBURN, M. UK women's experiences of breastfeeding and additional breastfeeding support: a qualitative study of Baby Café services. Bmc Pregnancy \& Childbirth, London, v. 15, n. 1, p. 1-12, 7 jul. 2015. https://doi.org/10.1186/s12884-015-0581-5

GRIMSHAW, K. E.; AKSOY, B.; PALMER, A.; JENNER, K.; OLIVER, E.M. MASKELL, J. Prospective food diaries demonstrate breastfeeding characteristics in a UK birth cohort. Matern Child Nutr, Southampton, v. 11, n. 4, p. 703-711, 18 jun. 2013. https://doi.org/10.1111/mcn.12052

HACKMAN, N. M.; SCHAEFER, E. W. Breastfeeding Outcome Comparison by Parity. Breastfeeding Medicine, Pennsylvania, v. 10, n. 3, p. 156-162, abr. 2015. https://doi.org/10.1089/bfm.2014.0119

KÖKSAL, E.; YALCIN, S. S. Complementary Feeding Practices of Children Aged 12-23 Months in Turkey. Central European Journal Of Public Health, Ankara, v. 23, n. 2, p. 149-154, jun. 2015. https://doi.org/10.21101/cejph.a3988

MARRONE, S.; VOGELTANZ-HOLM, N.; HOLM, J. Attitudes, Knowledge, and Intentions Related to Breastfeeding Among University Undergraduate Women and Men. Journal Of Human Lactation, Grand Forks, v. 24, n. 2, p. 186-192, mai. 2008.

MAZARIEGOS, M.; ZEA, M. R. Breastfeeding and non-communicable diseases later in life. Arch Latinoam Nutri, v. 65, n. 3, p. 143-151, 2015.

NAKAMURA, S. S.; VEIGA, K. V.; FERRARESE, S. R. B.; MARTINEZ, F. E. Percepção e conhecimento de meninas escolares sobre o aleitamento materno. J. Pediatr. Rio de Janeiro, v. 79, n. 2, p. 181-188, abr. 2003.

OLIVEIRA, F. S.; KERBER, N. P. C.; VAGHETTI, H. H.; LUNARDI, W. D.; WACHOLZET, W. D. L. A organização do trabalho das enfermeiras na assistência pré-natal: uma revisão integrativa. Cienc. Cuid. Saúde, Rio Grande, v. 11, n. 2, p. 368-375, 7 mar. 2012. https://doi.org/10.4025/cienccuidsaude.v11i2.14546 
OOSTERHOFF, A.; HUTTER, I.; HAISMA, H. It takes a mother to practise breastfeeding: Women's perceptions of breastfeeding during the period of intention. Women And Birth, Groningen, v. 27, n. 4, p.4350, dez. 2014. https://doi.org/10.1016/j.wombi.2014.08.003

QUEENAN, J. T. Academy of Breastfeeding Medicine Founder's Lecture 2010: Breastfeeding. Breastfeeding Medicine, Washington, v. 6, n. 1, p. 7-14, fev. 2011. https://doi.org/10.1089/bfm.2010.0103

SALUSTIANO, L. P. Q.; DINIZ, A. L. D.; ABDALLAH, V. O. S. PINTO, R. M. C. Fatores associados à duração do aleitamento materno em crianças menores de seis meses. Revista Brasileira de Ginecologia e Obstetrícia, Rio de Janeiro, v. 34, n. 1, p. 28-33, jan. 2012.

SEIGHALI, F., FARAHANI, Z., SHARIAT, M. The effects of two different breastfeeding workshops on improving knowledge, attitude, and practice of participants:a comparative study. Acta Med Iran, Tehran, v. 53, n. 7, p. 412-418, jun. 2015.

SHAMS, S. Breastfeeding and motherhood. Pakistan J. of Nutr, Faisalabad, v. 10, n. 6, p. 599-601. 2011. https://doi.org/10.3923/pjn.2011.599.601

SHARP, D.; ENTWISTLE, F. Why women stop breastfeeding in the early days. Pract Midwife, v. 18, n. 9, p. 30-33, out. 2015.

SILVA, N. M.; WATERKEMPER, R.; SILVA, E. F.; CORDOVA, F. P.; BONILHA, A. L. L. Conhecimento de puérperas sobre amamentação exclusiva. Revista Brasileira de Enfermagem, Brasilia, v. 67, n. 2, p. 290295, abr. 2014.

SILVA, T. Aleitamento materno: prevalência e fatores que influenciam a duração da sua modalidade exclusiva nos primeiros seis meses de idade. Acta Pediatr Port, v. 44, n. 5, p. 223-228, nov. 2013.

SOUZA, S. N. D. H.; MELLO, D. F.; MESQUITA, J. R. C. O aleitamento materno na perspectiva da vulnerabilidade programática e do cuidado. Caderno de Saúde Pública, Brasília, v. 29, n. 5, p. 1189-1194, jun. 2013. https://doi.org/10.1590/s0102-311x2013000600015

https://doi.org/10.1590/s0102-311x2013001000015

VENANCIO, S. I.; SALDIVA, S. R. D. M.; MONTEIRO, C. A. Tendência secular da amamentação. Rev Saúde Pública, São Paulo, v. 47, n. 6, p. 1205-1208, dec. 2013. https://doi.org/10.1590/S0034-89102013000901205

WALLWIENER, S.; MULLER, M.; DOSTER, A.; PLEWNIOK, K.; WALLWIENER, C.W.; RECK, C. Predictors of impaired breastfeeding initiation and maintenance in a diverse sample: what is important?. Arch Gynecol Obstet, v. 294, n. 3, p. 455-466, dez. 2015. https://doi.org/10.1007/s00404-015-3994-5

WARD, K. N.; BYRNE, J. P. A Critical Review of the Impact of Continuing Breastfeeding Education Provided to Nurses and Midwives. Journal Of Human Lactation, v. 27, n. 4, p. 381-393, jul. 2011.

https://doi.org/10.1177/0890334411411052 